\title{
The (im)plausibility of racism in Europe: policy frameworks on discrimination and integration
}

\section{SILVIA RODRÍGUEZ MAESO AND MARTA ARAÚJO}

\begin{abstract}
Rodríguez Maeso and Araújo analyse the reproduction of a dominant understanding of racism in policy discourses of integration and discrimination used by monitoring agencies in Portuguese and European Union (EU) institutional contexts. More specifically, they question the political concern over racism and discrimination vis-à-vis the idea of Europe 'becoming increasingly diverse' and the need to gather 'evidence' of discrimination. To that end, they examine periodic reports issued by EU monitoring agencies since the 1990s-paying specific attention to reporting on school segregation of Roma pupils in Portugal-and national integration policies and initiatives that, since the 2000s, have targeted mainly Roma and black families and youth. They argue that the dominant discourse of integration and cultural diversity conceives of racism as external to European political culture, and as a 'factor' of the 'conflictive nature' of social interactions in ethnoracially heterogeneous settings. This paves the way for calls for the 'strengthening of social cohesion'-on the assumption that policy initiatives need to act on the 'characteristics' of socalled 'vulnerable' populations-whereas institutional arrangements and everyday practices remain unchallenged.
\end{abstract}

KEYWORDS cultural diversity narratives, depoliticization, discrimination, Europe, institutional racism, integration discourse, monitoring agencies, Portugal, racism

In The Authoritarian Personality (1950), in the context of political acknowledgement of the Holocaust, Theodor Adorno and his colleagues aimed to provide a conceptual repertoire and a series of techniques for identifying, measuring, explaining and preventing 'the potential threat of the fascist mentality'. ${ }^{1}$ This collective endeavour, sponsored by the American Jewish Committee, was prompted by the quest to understand the roots of Nazi antisemitism.

Today the world scarcely remembers the mechanized persecution and extermination of millions of human beings only a short span of years away in what was once regarded as the citadel of Western civilization. Yet the conscience of many men was aroused. How could it be, they asked each other, that in a culture of law, order, and reason, there should have survived the irrational

1 T. W. Adorno, 'Types and syndromes', in T. W. Adorno, Else Frenkel-Brunswik, Daniel J. Levinson and R. Nevitt Sanford, The Authoritarian Personality, Studies in Prejudice Series, vol. 1 (New York: Harper \& Brothers 1950), 744-83 (748). 
remnants of ancient racial and religious hatreds? How could they explain the willingness of great masses of people to tolerate the mass extermination of their fellow citizens? What tissues in the life of our modern society remain cancerous, and despite our assumed enlightenment show the incongruous atavism of ancient peoples? And what within the individual organism responds to certain stimuli in our culture with attitudes and acts of destruc-tive aggression? ${ }^{2}$

Significantly, and as addressed throughout this article, key understand-ings of racism proposed then became hegemonic in academic research and embedded in politics and in policy formulations. This is particularly evident in the work of European political institutions and monitoring agencies, such as the former European Monitoring Centre on Racism and Xenophobia (EUMC), the Fundamental Rights Agency (FRA) and the Euro-pean Commission against Racism and Intolerance (ECRI). The aim of the EUMC (1998-2006) was to provide EU institutions and member states with reliable data on racism, xenophobia and antisemitism, and to identify best practice in countering them. In its first annual report it concluded that there was a risk of 'a rise in racism and xenophobia', although 'not to the extent that [Europe] experienced more than fifty years ago under a totalitar-ian regime, but by new, underhand forms which can prosper in a democratic society'. 3 The report acknowledged that racism was 'becoming mundane in daily life' and regarded with 'indifference' by institutions and the general population; 'foreign populations or ethnic minorities' were its main victims and repressive measures proved insufficient.

\footnotetext{
Welcoming foreign populations or those of foreign origin into the European Area must involve their integration and the granting of rights. Without this, they will be marginalised and rejected by the phenomenon of xenophobia. For these reasons an effective European immigration and asylum policy is essential to prevent racism. . . . For isolated acts of racism, just as for those com-mitted by organised groups, the threat of judicial proceedings is not strong enough. This is particularly true for extreme right wing political parties who, if they do not directly commit racist crimes, encourage them within public opinion by discriminatory ideologies which are infiltrating larger and larger segments of the population. All over Europe the 'sanitary cordon' against racism is weak. ${ }^{4}$
}

2 Max Horkheimer and Samuel H. Flowerman, 'Foreword to Studies in Prejudice', in ibid., vviii (v).

3 EUMC, Looking Reality in the Face: The Situation regarding Racism and Xenophobia in the European Community. Annual Report 1998. Part II, Dir/EZ-EUMC/177 (Vienna: EUMC 1999), 76, available on the FRA website at https://fra.europa.eu/sites/default/files/ fra_uploads/1944-AR_1998_part2-en.pdf (viewed 5 December 2016).

4 Ibid. 
As is evident in these two quotations, the narratives overlap in their approach to racism within the paradigm of prejudice studies. ${ }^{5}$ Significantly, both also deploy disease metaphors, ${ }^{6}$ projecting a notion of racism as an intru-der in the polity. Racism is thus confined to being a remnant or a hidden extrem-ist ideology that may spread (the 'rotten apple' imaginary) in an otherwise healthy society: 7 something external to western democracy, while also recog-nizing that Europe was historically hurt, even dramatically devastated by its effects (namely, the Holocaust). This approach stems from a Eurocentric epis-temology that assumes a progressively democratic and enlightened Europe that nonetheless needs to be protected from outbursts of racism and xenopho-bia. ${ }^{8}$ The series of volumes in The Authoritatian Personality have been highly influential in providing a theoretical approach and a grammar for the 'studies of prejudice' and more specifically for the analysis of racial prejudice, that is, 'irrational hostility'. Accordingly, as Max Horkheimer and Samuel H. Flowerman wrote in the Foreword, the challenge is its 'eradication', which implies, for the authors, 're-education, scientifically planned on the basis of understanding scientifically arrived at'. ${ }^{9}$ This approach pervades the EU's mainstreaming, since the 1990 s, of an integration discourse, ${ }^{10}$

5 See Julian Henriques, 'Social psychology and the politics of racism', in Julian Henriques, Wendy Hollway, Cathy Urwin, Couze Venn and Valerie Walkerdine, Changing the Subject: Psychology, Social Regulation and Subjectivity [1984] (London and New York: Routledge 1998), 60-90.

6 The use of disease metaphors to speak of racism is not recent. For instance, in her analysis of British media coverage of the publication of the Scarman (1981) and Mac-pherson (1999) reports, Sarah Neal observes how the disease metaphor was prevalent in the former. Headlines and slogans, such as 'The hatred that is poisoning all Britain', 'The disease that threatens our survival', 'The search for remedies' or 'The cures for Brixton', dominated media reaction to the Scarman report, published following civil unrest in Brixton. See Sarah Neal, 'The Scarman Report, the Macpherson Report and the media: how newspapers respond to race-centred social policy interventions', Journal of Social Policy, vol. 32, no. 1, 2003, 55-74 (64). The use of this type of metaphor has also been documented in public speeches in South Africa during the 1990s, where racism was seen as a 'poison of our nation's soul', 'a deadly tumour' and 'a cancer': Saskia Malan, 'Conceptual metaphors in South African political speeches (1994-2001)', Stellenbosch Papers in Linguistics, vol. 38, 2008, 73-106 (91).

7 See Henriques, 'Social psychology and the politics of racism', 62.

8 See Barnor Hesse, 'Im/plausible deniability: racism's conceptual double bind', Social Identities, vol. 10, no. 1, 2004, 9-29.

9 Horkheimer and Flowerman, 'Foreword to Studies in Prejudice', vii.

10 Politico-academic formulations of the notion of integration as related to the liberal principle of equal opportunities have circulated since the 1960s in the United Kingdom (see David Gillborn, 'Race', Ethnicity and Education: Teaching and Learning in Multi-Ethnic Schools (London: Unwin Hyman 1990), 139) and, since the 1940s in the United States, with, for instance, Gunnar Myrdal's work. See Silvia Rodríguez Maeso and Beatriz Cavia, 'Esquivando el racismo: el paradigma de la "integración" en las sociedades europeas y vasca contemporáneas', in Ignacio Irazutza and María Martínez (eds), De la identidad a la vulnerabilidad: Alteridad e integración en el País Vasco contemporáneo (Barcelona: Edicions Bellaterra 2014), 151-94 (154-9). 
which considers that the 'major aspect of post-war immigration . . has been the shift in the countries and regions of origin of those entering Europe.

This shift has produced larger groups of identifiable racial and ethnic minorities . . , 11

In this article, we argue that the integration discourse that is currently prevalent in the policy framework of the European Union (EU), ${ }^{12}$ as well as in the Portuguese context, renders racism a possibility, ${ }^{13}$ and reduces its significance to overt and intentional 'racist acts'. ${ }^{14}$ At present, declared anxieties about racism in Europe and policy efforts aimed at monitoring and tackling it fail to address its embeddedness in political culture, ${ }^{15}$ and therefore in institutional structures and practices. Our analysis thus focuses on two spheres in which this dominant understanding of racism is conveyed: first, the reports issued by EU monitoring agencies since the 1990s, and the paradigmatic case of the reporting of school segregation of Roma pupils and its incidence in Portugal; second, integration policies and initiatives in Portugal that, since the 2000s, target ethnically marked populations, mainly Roma, ${ }^{16}$ as well as black families and youth. The article draws on our analysis of policy documents and monitoring reports, as well as on data gathered through empirical fieldwork and parti-cipatory workshops, conducted between 2010 and 2012 in Portugal, with some sixty participants (decision-makers, NGO representatives, social workers and teachers). ${ }^{17}$

11 European Commission, Directorate General for Employment, Industrial Relations and Social Affairs (DGV), Legal Instruments to Combat Racism and Xenophobia (Luxembourg: Office for Official Publications of the European Communities 1993), 6, available on the EU Bookshop website at http://bookshop.europa.eu/en/legal-instruments-to-combat-racism-andxenophobia-pbCE7793740/ (viewed 5 December 2016).

12 We approach policies not as 'discrete decisions' but as 'a system of knowledge and beliefsideas about the causes of social problems, assumptions about how a society works and notions about appropriate solutions': David K. Cohen and Michael S. Garet, 'Reforming educational policy with applied social research', Harvard Educational Review, vol. 45, no. 1, 1975, 17-43 (21).

13 David Theo Goldberg, The Threat of Race: Reflections on Racial Neoliberalism (Oxford and Malden, MA: Wiley-Blackwell 2009), 151-98 (189).

14 See Paul Gilroy, 'The end of antiracism', in James Donald and Ali Rattansi, 'Race', Culture, and Difference (London: Sage Publications 1992), 49-61; and David Gillborn, Racism and Antiracism in Real Schools: Theory, Policy, Practice (Buckingham: Open Uni-versity Press 1995).

15 See Alana Lentin, 'Europe and the silence about race', European Journal of Social Theory, vol. 11 , no. $4,2008,487-503$.

16 The term 'Roma' is widely used and endorsed today by the Council of Europe. None-theless, it should be noted that the term 'Gypsy' has been used by several grassroots movements in Portugal and Spain.

17 Research carried out within the international project TOLERACE (see the introduction to this special issue). 
And then Europe responded: racism as ideology, irrationality and fantasy

During the 1990s, following several cases of racist violence and murders in Europe (from the numerous cases in Austria and Germany reported in inter-national media in the early 1990s to the perhaps most publicized murders of Stephen Lawrence in London in 1993 and Alcindo Monteiro in Lisbon in 1995), the EU agreed on the need for a democratic commitment to combat racism. This culminated in a series of political initiatives, namely: the Euro-pean Council's launch of the European Commission against Racism and Intolerance (ECRI) in 1993; the setting up in the EU, in 1997, of the now extinct European Monitoring Centre on Racism and Xenophobia (EUMC), replaced in 2007 by the European Union Fundamental Rights Agency (FRA), focused on multiple discrimination. In addition, there was the designation of 1997 as the European Year against Racism, and the 2000 adoption of the Racial Equality Directive (2000/43/EC), designed to implement an antidiscrimination legal framework and to mainstream measures across crucial policy intervention areas.

In this section, we focus on key analytical approaches to racism by the EUMC and its successor, the FRA, as well as by the ECRI. These bodies have aimed to provide comparative data and offer policy advice on the occur-rence of ethnoracial discrimination across Europe. To that end, we analysed the reports published by them from the late 1990 s to the 2010s. ${ }^{18}$

\section{Understanding and monitoring racism within Europe's 'increased diversity'}

Based on our analysis of the policy discourse of these monitoring bodies, we highlight three interrelated issues: (i) the historico-political narrative deployed regarding the presence of immigrants and minorities in European societies and social change; (ii) the pervasive understandings of racism, with implications in terms of how its occurrence can be detected and validated; (iii) the concern with gathering data on racism and discrimination, shifting the focus to the every-day lives of immigrants and minorities.

Regarding the first issue, despite the context in which the EUMC/FRA and the ECRI emerged, their reports' main narrative suggests that concerns over

18 The annual reports by the EUMC/FRA cover the 1998-2009 period, but we also ana-lysed the report prepared by the International Institute of Human Rights in Stras-bourg: DGV, Legal Instruments to Combat Racism and Xenophobia. This report drew on national reports from various member states, within the framework of the European Commission's resolution on the fight against racism and xenophobia adopted in the 29 May 1990 meeting (2). We consider it a significant precedent to the establishment of the EUMC in 1997. Regarding the ECRI, we analysed the documents on its launch and mandate and, following its country-bycountry approach, we examined the four published reports on Portugal (published in 1998, 2002, 2007 and 2013). 
the rise of racism are tied to perceptions of demographic changes in terms of ethnoracial diversity, accompanied by a warning of the possible difficulties that this new reality may bring. 19

In Belgium, the last Eurobarometer, which showed that $55 \%$ of Belgians were avowedly racist, provoked the following comment. 'There are several expla-nations for this view, even though one constant feature is the difficulty of coex-istence. First, of course, there has been an influx of foreigners, mainly from black Africa and Central Europe, who have arrived in Belgium to seek asylum. Belgium's reception policy is to distribute asylum seekers over recep-tion centres in small towns or villages where the local population are not always very happy to rub shoulders with people whose origins and cultures are often very different from their own and whom they feel have been thrust upon them. ${ }^{20}$

The EU's population is highly diverse and is becoming increasingly so. Along-side established minorities, such as the Roma and national minorities, immigra-tion from outside the EU has played a significant role in recent years in shaping the ethnic and cultural diversity of the Union. ${ }^{21}$

According to this narrative, the great challenge for institutions such as the FRA is combatting discrimination against immigrants from outside the EU, viewed as the cause of the growing diversity of the population within EU ter-ritories. This diagnosis of the challenges faced by the EU regarding 'diver-sity' and 'social cohesion' naturalizes - thus depoliticizing ${ }^{22}$ — the

19 This is particularly the case in regard to countries where the EUMC considers immi-gration to be new, such as 'Greece, Italy, Spain, Portugal, Finland, Ireland, and, to some extent, Denmark', which are contrasted to countries with 'a colonial past and also an early experience with foreign workers (e.g. France, the UK, the Netherlands)': EUMC, Migrants, Minorities and Education: Documenting Discrimination and Integration in 15 Member States of the European Union (Luxembourg: Office for Official Publications of the European Communities 2004), 10, also 92, available on the FRA website at http://fra.europa.eu/en/publication/2004/migrants-minorities-and-education (viewed 15 November 2016). See also Marta Araújo, 'Challenging narratives on diversity and immigration in Portugal: the (de)politicization of colonialism and racism', in Philip Kretsedemas, Jorge Capetillo-Ponce and Glenn Jacobs (eds), Migrant Marginal-ity: A Transnational Perspective (London and New York: Routledge 2013), 27-46.

20 EUMC, Looking Reality in the Face, 20.

21 FRA, EU-MIDIS at a Glance: Introduction to the FRA's EU-wide Discrimination Survey (Vienna: FRA 2009), 4 (emphasis added), available on the FRA website at http://fra. europa.eu/sites/default/files/fra_uploads/414-EU-MIDIS_GLANCE_EN.pdf (viewed 5 December 2016).

22 We follow here Wendy Brown's understanding of depoliticization as a process that 'involves removing a political phenomenon from comprehension of its historical emer-gence and from a recognition of the powers that produce and contour it. No matter its particular form and mechanics, depoliticization always eschews power and history in the representation of its subjects.': Wendy Brown, Regulating Aversion: Tolerance in the Age of Identity and Empire (Princeton, NJ: Princeton University Press 2006), 15 (empha-sis in the original). 
boundary between majority and minority populations through the (re)pro-duction of 'the immigrant imaginary'. This binds the hegemonic group to the idea of 'the national majority', ${ }^{23}$ via implicit and unexamined notions of Europe and Europeanness cut across by race. ${ }^{24}$ For instance, the ECRI's early action plan to deal with increasing diversity included a campaign that sought the 'enhancement of the European heritage', in order to 'reaffirm the importance we attach to the protection of our European cultural and natural heritage and to the promotion of awareness of this heritage'. 25 Conse-quently, groups marked by their migrant or minority 'background' are located within a naturalized distance. This distance is sustained by an inter-pretative paradigm that rests on the assumption of a foundational ethnic homogeneity within the nation, while conceding the need to recognize the 'positive' aspects of diversity, thus regulating and improving the relationships between the majority and ethnically marked populations. Racism becomes intelligible as an isolated exception within a historical narrative of a changing Europe shaped by imaginaries of 'new' and 'old' immigration flows, the erosion of 'social cohesion' and 'unassimilable minorities'. In this context, the political configuration of 'immigration', 'cultural diversity' and 'ethnic minorities' as key policy issues has reproduced race and racism, both concep-tually and politically. As David Theo Goldberg has stated:

\footnotetext{
Race has historically concerned the fabrication of social homogeneities, their making and their embroidery, arrangement and order, management and com-merce. Racism concerns the maintenance of homogeneities' contours, militariz-ing their borders, patrolling their places of possible transgression. ${ }^{26}$
}

Since the 1950s, this has supported specific political and policy frameworks and discourses, namely, solutions based on ideas of 'contact', 'integration' and 'assimilation'. 27

23 Barnor Hesse and S. Sayyid, 'Narrating the political postcolonial and the immigrant imaginary', in N. Ali, V. S. Kalra and S. Sayyid (eds), A Postcolonial People: South Asians in Britain (New York: Columbia University Press 2008), 13-31 (22-3).

24 On race and the idea of Europe, see Aníbal Quijano, 'Coloniality of power, Eurocentr-ism, and Latin America', Nepantla: Views from South, vol. 1, no. 3, 2000, 533-80; and Barnor Hesse, 'Racialized modernity: an analytics of white mythologies', Ethnic and Racial Studies, vol. 30, no. 4, 2007, 643-63.

25 Council of Europe, 'Second Summit of Heads of State and Government (Strasbourg, 10-11 October 1997): Final Declaration and Action Plan', CM(97)169, Strasbourg, 11 October 1997, 4 (emphasis in original), available on the Council of Europe website at https://wcd.coe.int/ViewDoc.jsp?id=593437\# (viewed 17 November 2016). See also the Council of Europe [First] Summit, 'Vienna Declaration', Decl-09.10.93, Vienna, 9 October 1993, available on the Council of Europe website at https://wcd.coe.int/ ViewDoc.jsp?id=621771 (viewed 17 November 2016).

26 Goldberg, The Threat of Race, 5.

27 Henriques, 'Social psychology and the politics of racism', 71-80. 
Regarding the second issue, the early reports published by the EUMC devoted a great deal of space to discussion of the notions of race, racism, xenophobia and their historicity. ${ }^{28}$ Overall, they suggested the difficulty of defining racismacademically this would be considered a highly complex and subjective phenomenon-and thus of developing reliable 'eva-luative instruments' ${ }^{29}$ Let us consider three examples, spanning over a decade.

Defining the scope of the problem is as difficult as regulating it, in part because racism and xenophobia are beliefs or attitudes. ${ }^{30}$

If, given the current evaluative instruments (police and court statistics, studies of victims and studies of the perpetrators of racist acts), it is difficult to obtain a clear picture of racism in Europe, one of the reasons put forward by sociologists is that this is a highly subjective phenomenon. Those responsible for racism or xenophobic attitudes rely more on ideology, irrationality and fantasy than on reasoned argument. $^{31}$

. . . the fact that in most cases no clear relations between certain respondents' characteristics and the amount of experienced discrimination could be found might well be seen as a finding itself. It can be interpreted as resulting from the complexity of the phenomenon. The question of whether or not one becomes the victim of discriminatory acts (or at least has the feeling that this was the case) does not seem to be a simple one. ${ }^{32}$

By approaching scientific knowledge through a positivist and presentist lens, these understandings gloss over long-term disagreement in political and academic debate regarding notions of, and approaches to, racism. For instance, it was precisely to contest the dominant understanding of racism as an irrational prejudice' of 'bigoted individuals' that had become prevalent that, in their 1967 book Black Power: The Politics of Liberation in America, Stokely Carmichael (aka Kwame Ture) and Charles Hamilton put forward the notion of institutional racism as something embedded in the normal workings of

28 DGV, Legal Instruments to Combat Racism and Xenophobia; EUMC, Looking Reality in the Face; EUMC, Racism and Xenophobia in the EU Member States: Trends, Developments and Good Practice in 2002. Annual Report-Part 2 (Vienna: EUMC 2002), available on the FRA website at http://fra.europa.eu/sites/default/files/fra_uploads/131-AR_02_part2_EN. pdf (viewed 5 December 2016).

29 EUMC, Looking Reality in the Face, 19.

30 DGV, Legal Instruments to Combat Racism and Xenophobia, 12 (emphasis added).

31 EUMC, Looking Reality in the Face, 19 (emphasis added).

32 EUMC, Migrants' Experiences of Racism and Xenophobia in 12 EU Member States. Pilot Study (Vienna: EUMC 2006), 124 (emphasis added), available on the FRA website at http://fra.europa.eu/sites/default/files/fra_uploads/224-Migrants-Experiences-web.pdf (viewed 5 December 2016). 
western liberal institutions. ${ }^{33}$ This is not only a crucial notion for critical scholarship on race, as it also reveals that specific conceptions of racism have always been contested. Hence, while not denying the complexity of racism as a phenomenon, we see the constant deployment of the complexity argument as a means to both constrain its scope and justify political ambivalence towards antiracism, as illustrated in the quotes above. ${ }^{34}$ More precisely-in contrast to what European institutions have suggested-it is not that we do not know exactly what racism is and that we need more knowledge; rather, the issue revolves around knowledge, ${ }^{35}$ that is, around the knowledge that we (re)produce. Specifically, dominant knowledge production has marginalized understandings and approaches that acknowledge the historical and political foundations of racism in Europe. As we show below, these crucial questions are erased from the debate.

Motivated by the need to make the concept of racism operational, the FRA adopted the definition of racism proposed in section I.1.a of the ECRI's General Policy Recommendation No. 7 on national legislation to combat racism: "racism" shall mean the belief that a ground such as race, colour, language, religion, nationality or national or ethnic origin justifies contempt for a person or a group of persons, or the notion of superiority of a person or a group of persons. ${ }^{36}$ This shared conception fails to locate racism in a pol-itical culture and in institutional arrangements and practices that are the legacy of colonial governance. ${ }^{37}$ Rather, racism is reduced to prejudice, that is, to the existence of beliefs based on erroneous judgement, ${ }^{38}$ as opposed to the correct processing of information and unbiased representation of ethnically

33 Stokely Carmichael and Charles V. Hamilton, Black Power: The Politics of Liberation in America (New York: Random House 1967). For a genealogy of the notion of institutional racism, see Barnor Hesse, 'Discourse on institutional racism: the genealogy of a concept', in Ian Law, Deborah Phillips and Laura Turney, Institutional Racism in Higher Education (Stoke on Trent: Trentham Books 2004), 131-47.

34 For instance, it is very telling that in conferences we have attended to present this pro-ject's findings, we tend to be disproportionately questioned about our definition of racism, in a way that our colleagues working on notions of tolerance, social cohesion, radicalization, immigration and human rights are not.

35 See Philomena Essed and Kwame Nimako, 'Designs and (co)incidents: cultures of scholarship and public policy on immigrants/minorities in the Netherlands', Inter-national Journal of Comparative Sociology, vol. 47, no. 3-4, 2006, 281-312.

36 ECRI, General Policy Recommendation No. 7: On National Legislation to Combat Racism and Racial Discrimination, CRI(2003)8, adopted 13 December 2002 (Strasbourg: ECRI 2003), 5, available on the Council of Europe website at www.coe.int/t/dghl/monitoring/ecri/ activities/GPR/EN/Recommendation_N7/ecri03-8\%20recommendation\%20nr\%207. pdf (viewed 17 November 2016); see also FRA, 'Data collection and research activities on racism and xenophobia in the EUMC (1998-2006): lessons learned for the EU Fundamental Rights Agency', Working Paper (Vienna: FRA 2007), 29-30.

37 See Hesse, 'Im/plausible deniability', 24.

38 See Henriques, 'Social psychology and the politics of racism'; and David Theo Gold-berg, 'Racism and rationality: the need for a new critique', Philosophy of the Social Sciences, vol. 20, no. 3, 1990, 317-50. 
marked populations (i.e. immigrants and minorities), beliefs that could lead to 'contempt' or 'feelings of superiority'. Accordingly, racism is proven through the identification of the racist individual/group, ${ }^{39}$ and an emphasis is placed on questions related to the reliability of instruments of evaluation to certify ('feel-ings of') ethnoracial discrimination. This concern is at the heart of the EU Mi-norities and Discrimination Survey (EU MIDIS), aimed at polling 'selected immigrant, ethnic minority and national minority groups in all 27 EU Member States about their experiences of discrimination and victimisation'. ${ }^{40}$ Rather than investing in the means to identify and tackle racism in insti-tutional structures, processes and practices ${ }^{41}$-with the required change of approach and focus-the mandate of monitoring racism becomes instead directed towards detecting (dubious) feelings of maltreatment.

Finally, the third issue refers to the perceived lack of sufficient evidence of experiences of racism and discrimination, which justifies current insufficient policy action by the governments of member states.

\begin{abstract}
Member States with either limited official reporting or no official reporting on racist crime are not in the best position to develop evidence-based policy responses to the problem. Against this backdrop there are some encouraging developments with respect to Member States beginning to acknowledge the significance of racist crime as a social ill. ${ }^{42}$
\end{abstract}

We have discussed elsewhere the discourse on racism in relation to "evidence-based policy-making' and the role of the social sciences in providing know-ledge for 'better informed' policy decisions. ${ }^{43}$ Here we would like to highlight how (the perception of) insufficient information regarding racism is connected with an understanding of the phenomenon as highly subjective and complex, thus leading to low reporting figures.

... the high rate of subjectively experienced discrimination should be regarded as both cause and expression of dissatisfaction among migrants with their current status within society. Moreover, the perception of being occasionally or systematically discriminated against on racist or xenophobic grounds should be regarded as bearing the potential of contributing to an alienation of affected groups with

39 For a critique of the idea of the 'racist subject', see, for instance, Philomena Essed, Understanding Everyday Racism: An Interdisciplinary Theory (Newbury Park, CA, London and Delhi: Sage 1991).

40 FRA, EU-MIDIS Technical Report: Methodology, Sampling and Fieldwork (Vienna: FRA 2009), 6, available on the FRA website at http://fra.europa.eu/sites/default/files/eumidis_technical_report.pdf (viewed 17 November 2016).

41 See Essed, Understanding Everyday Racism.

42 FRA, Annual Report 2008 (Vienna: FRA 2008), 9 (emphasis added).

43 Silvia Rodríguez Maeso and Marta Araújo, 'The politics of (anti-)racism: academic research and policy discourse in Europe', in Wulf D. Hund and Alana Lentin (eds), Racism and Sociology, Racism Analysis, Yearbook 5 (Münster and Berlin: Lit-Verlag 2014), 207-37 (213-17). 
the society and political system they live in. A remarkable result of the pilot study is the low overall rate of reporting discrimination to authorities....

Finally, the fact that most data do not allow the construction of simple explanations for causes of discriminatory experiences can be interpreted as a finding itself. It should be interpreted as representing the complex nature of racism and discrimination. $^{44}$

The collection of empirical data for the development of policies and action in the field of fundamental rights lies at the heart of the FRA's mandate. This 'bottom up' approach to data collection on the situation of fundamental rights, which directly engages those who are vulnerable to fundamental rights abuses, serves to shed new light on the experiences of ethnic minorities and immigrants in the EU. ${ }^{45}$

Rather than examining the causes of victim wariness towards authorities, this approach somehow questions the plausibility of racism as a cause of current ethnoracial inequalities and situations of discrimination. It thus places the victims of racism under suspicion. As evident in the latter quote, there is a swift shift to an emphasis on the lack of experiences of everyday life and inte-gration, rather than of racism.

... policy-makers remain ill-informed about how minorities experience everyday life in the Member States. ${ }^{46}$

... there is a severe lack of data on minorities in many countries. Data is [sic] needed to measure minorities' integration into European societies, as well as the extent of discriminatory treatment and criminal victimisation, including racially motivated crime, experienced by minorities. ${ }^{47}$

In this context, it should be noted how the concept of institutional racism is ultimately evaded, ${ }^{48}$ even though it appears to be the logic that informs the data collected in the specific spheres of life selected by the FRA (i.e. education, health, housing, media and violence).

44 EUMC, Migrants' Experiences of Racism and Xenophobia in 12 EU Member States, 127 (emphasis added).

45 FRA, EU-MIDIS European Union Minorities and Discrimination Survey: Main Results Report (Vienna: FRA 2009), 7 (emphasis added), available on the FRA website at http://fra.europa.eu/sites/default/files/fra_uploads/664-eumidis_mainreport_conferenceedition_en_.pdf (viewed 5 December 20160.

46 FRA, 'European Union Minority and Discrimination Survey (EU-MIDIS)', Memo, 22 April 2009, 5, available on the FRA website at http://fra.europa.eu/sites/default/files/ fra_uploads/410-EU-MIDIS_memo_en.pdf (viewed 17 November 2016).

47 FRA, EU-MIDIS at a Glance, 4 (emphasis added).

48 We draw on the notion of institutional racism proposed in Carmichael and Hamilton, Black Power, which points to the need to overcome the ideas of intentionality and prejudice, and focus on the structures, processes and routine practices embedded in western liberal democracies. 


\section{Cases of school segregation in Portugal: racism as 'an avenue to be explored'}

Let us now consider the policy discourses on school segregation of Roma chil-dren in Portugal contained in EUMC/FRA and ECRI reports. These reports are fundamental to the mobilization of condemnation by reporting the regular occurrence of school segregation affecting Roma students in particular. This is especially the case in Portugal, due to the absence of mechanisms for moni-toring and publishing data on ethnoracial discrimination. ${ }^{49}$ It should further be noted that the government has remained silent on the question of school segregation in its National Roma Communities Integration Strategy. 50

Since the early 2000s, cases of school segregation have been widely reported in relation to several member states, ${ }^{51}$ with the EUMC/FRA later conceding that it was 'a common phenomenon in large parts of the EU', 52 targeting Roma pupils and often associated with spatial segregation. ${ }^{53}$ The ECRI and the Council of Europe $(\mathrm{CoE})$, in Recommendations Adopted by the Committee of Ministers, ${ }^{54}$ also emphasized the long history of education policies that could 'lead either to assimilation or to segregation of Roma and Traveller chil-dren at school on the grounds that they were "socially and culturally handi-capped"". 55 Accordingly, the $\mathrm{CoE}$ called on its members states to "take urgent measures, including legal and political ones', to end both inter- and intra-school segregation. ${ }^{56}$ Segregated schooling is considered the result of

49 See Araújo, 'Challenging narratives on diversity and immigration in Portugal'.

50 Alto Comissariado para a Imigração e Diálogo Intercultural (ACIDI), National Roma Communities Integration Strategy (2013-2020) (Lisbon: ACIDI 2013), available on the European Commission website at http://ec.europa.eu/justice/discrimination/files/ roma_portugal_strategy_en.pdf (viewed 18 November 2016). See also Marta Araújo, 'A very "prudent integration": white flight, school segregation and the depoliticization of (anti)racism', Race, Ethnicity and Education, vol. 19, no. 2, 2016, 300-23.

51 EUMC, Racism and Xenophobia in the EU Member States, 30.

52 Ibid., 14; see also FRA, Report on Racism and Xenophobia in the Member States of the EU (Vienna: FRA 2007), 106, available on the FRA website at http://fra.europa.eu/sites/ default/files/fra_uploads/11-ar07p2_en.pdf (viewed 5 December 2016); and FRA, Annual Report 2008.

53 EUMC, Racism and Xenophobia in the EU Member States, 30.

$54 \mathrm{CoE}$, 'Recommendation CM/Rec(2009)4 of the Committee of Ministers to member states on the education of Roma and Travellers in Europe', adopted 17 June 2009, available on the $\mathrm{CoE}$ website at https://search.coe.int/cm/Pages/result_details.aspx? ObjectID=09000016805b0a1c (viewed 5 December 2016).

55 Ibid. See also ECRI, General Policy Recommendation No. 10: On Combating Racism and Racial Discrimination in and through School Education, CRI(2007)6, adopted 15 December 2006 (Strasbourg: ECRI 2007), 4, available on the CoE website at www.coe.int/t/dghl/ monitoring/ecri/activities/GPR/EN/Recommendation_N10/eng-recommendation\%20nr \%2010.pdf (viewed 5 December 2016).

56 ECRI, Recommendation No. 13 on Combating Anti-Gypsyism and Discrimination against Roma, CRI(2011)37, adopted 24 June 2011 (Strasbourg: ECRI 2011), 5, available on the $\mathrm{CoE}$ website at https://www.coe.int/t/dghl/monitoring/ecri/activities/GPR/EN/ Recommendation_N13/e-RPG\%2013\%20-\%20A4.pdf (viewed 5 December 2016). 
decisions by school staff, parental pressure and the 'freedom to choose', 57 allowing children to enrol in schools outside their catchment area, ${ }^{58}$ a process known as white flight. ${ }^{59}$ Although not necessarily explicit regarding the grounds of race/ethnicity that motivate it, school segregation is interpreted as direct discrimination: 'individual acts and institutional practices of a racist and xenophobic character' that take different forms including intra-class and intra- and inter-school segregation. ${ }^{60}$

Focusing more specifically on the reports by the ECRI, as they follow a countryby-country-approach and offer a greater in-depth treatment, the same analytical approaches and interpretations emphasized in the section above can be seen to operate. First, regarding the narrative deployed to account for the presence of Roma in Portuguese society and the need for social change. Although Roma populations have lived for over five centuries in Europe, including in Portugal, in the reports they are still treated as newcom-ers who pose specific challenges to established society. Consequently, the 'Roma/ Gypsy question' has been addressed as something that is a natural reaction of 'hostility' resulting from 'the arrival of Roma/Gypsy groups in certain neigh-bourhoods', 'caused when different lifestyles coexist side by side. The estab-lished, sedentary population often sees the arrival of travelling people in their neighbourhood as a threat. ${ }^{, 61}$

Second, regarding understandings of racism, the ECRI's approach to cases of Roma school segregation in Portugal has been characterized by its depoli-ticization, namely, by interpreting them as a series of 'occasional', isolated events swiftly resolved by competent authorities once they have been prop-erly denounced. The following example is illustrative.

ECRI is especially concerned to learn that Gypsy children are occasionally faced with hostile reactions from parents of non-Gypsy children who do not wish Gypsy chil-dren to join their own children's classes. For example, ECRI notes the incident widely reported in the press of the transfer of ten or so Gypsy children from

57 EUMC, Racism and Xenophobia in the EU Member States, 30.

58 Such as parental 'avoidance strategies' to prevent their children attending schools in their catchment area. See FRA, Fundamental Rights: Challenges and Achievements in 2011, Annual Report (Vienna: FRA 2012), 57, available on the FRA website at http:// fra.europa.eu/sites/default/files/fra_uploads/2211-FRA-2012_Annual-Report-2011_EN. pdf (viewed 5 December 2016); and Araújo, 'A very "prudent integration"'.

59 The term white flight was popularized in debates on the desegregation of public schools in the United States in the 1970s to describe the significant number of white families moving to the suburbs to avoid integrated schooling.

60 EUMC, The Annual Report on the Situation regarding Racism and Xenophobia in the Member States of the EU, Annual Report 2005 (Vienna: EUMC 2006), 75, 78, available on the FRA website at http://fra.europa.eu/sites/default/files/fra_uploads/10-ar06p2_ en.pdf (viewed 5 December 2016).

61 ECRI, First Report on Portugal, CRI98(50) (Strasbourg: Council of Europe 1998), 9, 7-8, available on the UNHCR refword website at www.refworld.org/pdfid/51beeba74.pdf (viewed 5 December 2016). 
a school in Teivas to a school in Rebordinho at the start of the 2003 school year. The children were transferred apparently in response to pressure from non-Gypsy parents in the first school. Placards were put up in the new school stating 'No to Gypsies'. Nonetheless, the school officials reported the incident to the police and, according to ACIME [High Commission on Immigration and Ethnic Minorities], the authorities did everything to ensure that the Gypsy children could attend their new school under acceptable conditions. $^{62}$

It should also be noted that none of the four ECRI reports published on Por-tugal refer to cases of segregation as such. Rather, the reports reveal a hesitant approach to racism, broadly overlooking the role of institutions and auth-orities and failing to link it meaningfully to the historical suppression and repression of Roma throughout Europe.

Third, rather than a concern with improving the mechanisms of gathering and publishing data on the experiences of racism and discrimination, we can see a shift in the focus of political intervention towards the everyday lives of immigrants and minorities. While not completely evading questions of discrimination, the reports do not systematically address racism. Their focus is on a 'feeling of mutual mistrust', 63 emphasizing the changes required from the Roma population: improved school attendance, lower dropout rates and a weakening of the 'patriarchal elements' within the Roma community. ${ }^{64}$ This is in line with the political solution proposed by European institutions: the integration of Roma populations. An example of this is the EU Framework for National Roma Integration Strategies adopted in 2011, which calls for the drafting of national plans as 'an unprecedented commitment towards promot-ing Roma inclusion' by EU member states, to be implemented up to $2020 .^{65}$

Overall, our analysis of the ECRI reports on school segregation in Portugal reveals the persistence of a naive belief in the will of authorities to endorse political change, within an understanding of racism as a matter of intentionality and lack of awareness and mutual respect. ${ }^{66}$ What is missing from this approach

62 ECRI, Third Report on Portugal, CRI(2007)4 (Strasbourg: Council of Europe 2007), 30 (emphasis added), available on the $\mathrm{CoE}$ website at www.coe.int/t/dghl/monitoring/ ecri/Country-by-country/Portugal/PRT-CbC-III-2007-4-ENG.pdf (viewed 5 December 2016).

63 ECRI, ECRI Report on Portugal (Fourth Monitoring Cycle), CRI(2013)20 (Strasbourg: Council of Europe 2013), 20, available on the CoE website at www.coe.int/t/dghl/ monitoring/ecri/Country-by-country/Portugal/PRT-CbC-IV-2013-020-ENG.pdf (viewed 5 December 2016).

64 Ibid., 22.

65 European Commission, 'EU Framework', available on the European Commission website at http://ec.europa.eu/justice/discrimination/roma/eu-framework/index_en. htm (viewed 6 December 2016).

66 See, for example, ECRI, Second Report on Portugal, CRI(2002)33 (Strasbourg: Council of Europe 2002), 21-2, available on the CoE website at www.coe.int/t/dghl/monitoring/ ecri/Country-by-country/Portugal/PRT-CbC-II-2002-033-EN.pdf (viewed 5 December 2016); ECRI, Third Report on Portugal, 23. 
is a clear take on racism in which discrimination is seen as the tip of the iceberg of wider structures of power and routine pragmatics of racist governance, ${ }^{67}$ thus challenging the plausibility of racism.

\begin{abstract}
It is difficult to say with any degree of accuracy the role played by racist prejudices and racial discrimination in the treatment of immigrants and people from immigrant backgrounds since no statistics based on ethnic origin have yet been compiled. However, surveys and testimonies indicate that this is an avenue to be explored in order to understand the social exclusion suffered by certain immigrants. ${ }^{68}$
\end{abstract}

\title{
Diversity and integration as political and policy issues in Portugal
}

So far we have shown how the configuration of 'immigration', 'cultural diver-sity' and 'ethnic minorities' as key political issues has reproduced a specific narrative regarding discrimination within European monitoring agencies, whereby ethnically unmarked homogeneities (that is, European national states) have been disturbed by an increasing diversity with unwanted nega-tive effects, such as the rise of racism. In this section we analyse the performa-tivity of this narrative in integration policies in Portugal. Integration is presented as a process of social engineering, that is, a realignment of ethnically marked people and institutions/organizations, in which the former become 'problems' to be managed by the latter (so as to 'reinforce social cohesion'). Although racism and discrimination feature as areas of intervention or as requiring measures in policymaking, they are subsumed under the general framework of intervention targeting ethnically marked people and their con-dition of 'vulnerability', particularly Roma, black families and youth.

\section{Diversity and integration in policy discourse}

The normalizing definition of the boundary between 'Portuguese society' and the Other places it at the centre of concern of government action within a dis-course that hinges on three key ideas: integration of immigrants, reinforcement of social cohesion, and the promotion of cultural diversity and intercultural dia-logue, as expressed in the first and second Plano para a Integração do Imi-grantes (PII, Plan for Immigrant Integration). ${ }^{69}$ The narrative of Portugal as increasingly diverse and the need to address this newness are central.

67 See Essed, Understanding Everyday Racism, 43; Hesse, 'Discourse on institutional racism, the genealogy of a concept', 144.

68 ECRI, Third Report on Portugal, 21 (emphasis added).

69 For the PII, covering the period 2007-9, see 'Resolução do Conselho de Ministros No. 63A/2007', 2 May 2007, Diário da República, 1st Series, No. 85, 3 May 2007, available online at www.sg.min-saude.pt/NR/rdonlyres/A110CE46-A607-4BD1-AB82-BE86B31 


\begin{abstract}
Being traditionally an emigration country, since the 1990s Portugal has also become a country of immigration. The statistics show that nowadays immigrants make up 9 per cent of the active population and 4.5 per cent of the national popu-lation. Given this, the migration phenomenon brings new features to Portuguese society. On the one hand, it makes an important contribution towards the demo-graphic situation. On the other, it is a positive factor for economic growth, for a sustainable social welfare system, and for the cultural enrichment of the country. Nevertheless, this reality also entails government accountability for the inte-gration of these citizens, in particular the importance of social cohesion and of a better integration and management of cultural diversity. $^{70}$
\end{abstract}

The PII downplays the role of the demographic and economic contributions of immigrants, which are now confined to the sphere of diversity and the valorization of their 'cultures of origin' ${ }^{71}$ The focus is placed rather on the need to strengthen social cohesion in the 'current context of an international economic crisis' that 'exposes these citizens [immigrants] to a higher risk of social exclusion, given their greater vulnerability to social problems'. ${ }^{2}$ How are racism and discrimination addressed within such a framework? We high-light two main issues, connected with those identified in the previous section. First, the commitment to 'strengthen the competencies and the capacity for intervention' of the Comissão para a Igualdade e contra a Discriminação Racial (CICDR, Commission for Equality and against Racial Discrimi-nation $)^{73}$ - the equality body established for the promotion of equal treatment following the implementation of the European Race Equality Directive (2000/ 43/EC) and the Employment Equality Directive (2000/78/EC)—is reinforced in the PII, the objectives of which include 'approving a proposal to amend the current legal framework governing administrative offence procedures for dis-crimination on grounds of nationality or ethnic origin, in order to make these procedures more effective'. ${ }^{74}$ In fact, European monitoring agencies, a Portu-guese private research institute, as well as the RAXEN National Focal Point for Portugal, ${ }^{75}$ had already pointed to the CICDR's poor performance: the scarcity

314C3/18612/00020024.pdf; for the PII, covering the period 2010-13, see 'Resolução do Conselho de Ministros No. 74/2010', 12 August 2010, Diário da República, 1st Series, No. 182, 17 September 2010, available on the Diário da República Electrónica website at https://dre.pt/application/dir/pdf1sdip/2010/09/18200/0409704116.pdf (both viewed 21 November 2016).

70 'Resolução do Conselho de Ministros No. 63-A/2007', 2964-(2). Translations from the Portuguese, unless otherwise stated, are by the authors.

71 'Resolução do Conselho de Ministros No. 74/2010', 4099.

72 Ibid., 4097.

73 'Resolução do Conselho de Ministros No. 63-A/2007', 2964-(12); see also 'Resolução do Conselho de Ministros No. 74/2010', 4103.

74 'Resolução do Conselho de Ministros No. 74/2010', 4103.

75 Among the fifteen National Focal Points of the European RAcism and XEnophobia Network, one for each member state, is the Centro de Investigação em Ciencias Sociais e Humanas (Númena). 
of registered complaints, the lack of political independence and an insignifi-cant number of procedures. ${ }^{76}$ However, none of the structural changes that could enable the strengthening of CICDR had been achieved by the end of these two three-year periods of the PII. ${ }^{77}$ In 2014 , a commitment to change was again officially declared. Pedro Lomba, a deputy to the former Minister for Regional Development who had been coordinating the ongoing institutional and policy changes on integration and immigration issues, stated: ' . . . we are thinking of enhancing the effectiveness of the legal instruments available and also of reviewing how the existing Commission against Racial Discrimination [that is, CICDR] operates . . . I want to make some changes in its operation and composition, with the aim of improving its efficiency. $^{\text {,78 }}$

Second, the development of training, sensitization and consciouness-raising activi-ties, ${ }^{79}$ as well as public events, is a central aspect across every sector. The PII

76 European Network against Racism (ENAR), Rapport alternatif d'ENAR 2006: Racisme au Portugal (Brussels: Réseau Européen contre le racisme 2007), 25, available online at http://cms.horus.be/files/99935/MediaArchive/pdf/Portugal_2006.pdf (viewed 5 December 2016); ECRI, Third Report on Portugal, 13-14; FRA, Annual Report 2008, 23; Númena, O Racismo y Xenofobia en Portugal (2001-2007) (Oeiras: Númena 2008), 15.

77 In April 2013 the government presented a proposal to amend anti-discrimination legislation. However, to date, the proposal is 'on hold' and has not yet been discussed by the National Assembly. Neither was the proposal discussed by the members of the CICDR (according to the authors' personal communication with a commission member in December 2014). Regarding the proposal, see Joana Gorjão Henriques, 'Governo quer duplicar tecto máximo de multas por discriminação racial', Público, 9 April 2013, available on the Público website at www.publico.pt/portugal/jornal/ governo-quer-duplicar-tecto-maximo-de-multas-pordiscriminacao-racial-26350503 (viewed 23 November 2016).

78 Andreia Sanches, 'Pedro Lomba: "Os novos portugueses, descendentes de comuni-dades de imigrantes, precisam de uma nova atenção"', Público (online), 28 August 2014, available at www.publico.pt/n1667796 (viewed 20 November 2016). It should also be noted that the PII established a commitment: 'To collect and work with racial discrimination data, disaggregated by sex, gathered under administrative offence procedures for discrimination in general, in the sphere of employment' ('Reso-lução do Conselho de Ministros No. 74/2010', 4103). This is related to the transposing of parts of the European Race Equality Directive (2000/43/EC) and the Employment Equality Directive (2000/78/EC) into the Employment Law (that is, the 2009 amend-ment, Ley 7/2009 of 12 February). The CICDR does not conduct enquiries into com-plaints about employment discrimination, which must be addressed to the Autoridade para as Condições do Trabalho (ACT, Working Conditions Authority). According to a public employee of the ACT, interviewed in March 2011, the number of racial discrimination complaints is very low, as is the number of adminis-trative offence procedures and penalties. In the opinion of the interviewee, this meant that racial discrimination was not an issue in Portugal. To date there are no public records available on the number of relevant reports or administrative procedures.

79 For instance, regarding racism in sports or racial stereotyping in the mass media. Ways that could be used to determine the success of these measures are limited to the organization of events (such as seminars) or campaigns (such as the number of leaflets and brochures distributed, the number of schools participating in activities organized around these topics, or the 'number of studies produced'); and the 
reinforces the idea of a direct relationship between the fight against discrimination, integration and the promotion of diversity via training and sensitization activities in different sectors and with different social agents, such as cultural entrepreneurs, teachers and the media. ${ }^{80}$ Moreover, the 'promotion of diversity and interculturality' features as a new area of intervention, ${ }^{81}$ fuelling the widespread belief that recognizing the 'positive' aspects of diversity improves the relationships between the national majority and ethnic minorities and therefore further promotes 'equal opportunities', as we will analyse in detail in the next section. There is also much emphasis on the Programa Escolhas (Choices Programme), Portugal's flagship integration initiative since the early 2000s, that seeks 'to disseminate the work carried out by the programme's projects reflecting a more positive image of the socioeconomic contexts in which immigrants are integrated'. 82

\section{Integration policies, racism and ethnoracial diversity}

Launched in 2001, Programa Escolhas was initially aimed at 'crime prevention and the inclusion of youth' from 'the most vulnerable neighbourhoods in the districts of Lisbon, Porto, and Setúbal'. ${ }^{83}$ In 2004 it became national in scope and renewable every three years. In its fifth generation (2013-15), it focused explicitly on descendants of immigrants and ethnic minorities. Since 2007 the programme has been fully embedded in the Alto Comissariado para a Imi-gração e Diálogo Intercultural (ACIDI, High Commission for Immigration and Intercultural Dialogue) - renamed the Alto Comissariado para as Migrações (ACM, High Commission for Migrations) in 2004-a public body that over-sees most integration policies, as well as initiatives against racism and xeno-phobia in Portugal. Programa Escolhas sponsors projects proposed by public bodies and civil society associations, including town halls, children and youth protection commissions, immigrant and Roma organizations, youth associations, schools and the security forces. ${ }^{84}$ It is defined as 'a nation-wide programme that aims to promote social inclusion of children and youths from the most vulnerable socioeconomic contexts, particularly descendants of immigrants and ethnic minorities, ${ }^{85}$ with a view towards furthering equal

amount of relevant documentation produced by international organizations that the Gabinete para os Meios de Comunicação Social (Office for Media) has sent to the media. See 'Resolução do Conselho de Ministros No. 63-A/2007', 2964-(19), 2964(21).

80 'Resolução do Conselho de Ministros No. 74/2010', 4099 (measure 13), 4100 (measure 23), 4104 (measure 67), 4109.

81 Ibid., 4105-6.

82 Ibid., 4104.

83 'Resolução do Conselho de Ministros No. 4/2001', 9 January 2001, Diário da República, 1st Series-B, 9 January 2001, 69, available on the Diário da República Electrónica website at https://dre.pt/application/file/238954 (viewed 21 November 2016).

84 Projects are proposed and coordinated by consortia of at least four institutions (before 2012 the minimum number required was three).

85 Aged 6-24. 
opportunities and strengthening social cohesion'. ${ }^{86}$ In the official regulatory directive of 2012, there is no mention of ethnic minorities and Programa Escol-has is described as specifically targeting (as 'direct participants') 'descendants of immigrants and Roma communities' associated with, for instance, early school drop-out and absenteeism, unemployment or 'deviant behaviour'. ${ }^{87}$ As recorded in the external evaluation, covering the 2010-12 period, and using its categorization system, out of 312 projects funded by the programme (data from June 2011), 29 per cent targeted Roma youth and families, 33 per cent descendants of immigrants, and 38 per cent 'other Portuguese'. 88

Since 2009, the programme has emphasized interventions in the field of 'employability' and 'entrepreneurship', as well as 'personal, social, and par-enting competencies' and 'co-responsibility', as the heart of its 'positive' and 'proactive' approach towards integration. ${ }^{89}$ That rationale articulates the notion of 'successful inclusion' with a certain understanding of racism that attributes it either to universal prejudice or to conflict between minorities. As we have pointed out, the discourse of integration reproduces the boundary between the 'national majority', on the one hand, and 'ethnic minorities' and 'immigrants', on the other. Public policies enforce that boundary by assuming the need to 'familiarize' the latter with state institutions and national culture. In this regard, the programme has endorsed: 'Activities that promote the dis-covery, in a playful way, of the language, values, traditions, culture, and history of Portugal and the immigrant communities' countries of origin. ${ }^{\text {'90 This }}$ was reformulated in the directive so as to include: 'Activities that promote cooperation with security forces and services, ${ }^{91}$ such as the

86 'Resolução do Conselho de Ministros No. 68/2012', Diário da República, 1st Series, No. 154, 9 August 2012, 4279, available on the Diário da República Electrónica website at https://dre.pt/application/file/175252 (viewed 21 November 2016). This is the defini-tion commonly used in the programme's webpage and its periodical publication Revista Escolhas.

87 'Gabinete do Secretário de Estado Adjunto do Ministro Adjunto e dos Assuntos Parlamentares: Despacho normativo No. 17/2012', Diário da República, 2nd Series, No. 158, 16 August 2012, 29007, available on the Diário da República Electrónica website at https://dre.pt/application/dir/pdf2sdip/2012/08/158000000/2900629014.pdf (viewed 21 November 2016).

88 Ana de Saint-Maurice (ed.), Avaliação Externa do Programa Escolhas 2010-2012: Relatório Final (Lisbon: CET/ISCTE 2013), 80, available on the Programa Escolhas website at www.programaescolhas.pt/_cf/356618 (viewed 21 November 2016).

89 See the two last regulatory directives for the programme, published in 2009 and 2012: 'Gabinete do Ministro da Presidência. Despacho normativo No. 27/2009', Diário da República, 2nd Series, No. 151, 6 August 2009, available on the Diário da República Electrónica website at https://dre.pt/application/dir/pdf2sdip/2009/08/151000000/ 3143731444.pdf (viewed 21 November 2016); 'Gabinete do Secretário de Estado Adjunto do Ministro Adjunto e dos Assuntos Parlamentares: Despacho normativo No. 17/2012'.

90 'Gabinete do Ministro da Presidência. Despacho normativo No. 27/2009', 31437.

91 'Gabinete do Secretário de Estado Adjunto do Ministro Adjunto e dos Assuntos Parlamentares: Despacho normativo No. 17/2012', 29006. 
Serviço de Estrangeiros e Fronteiras (SEF, Foreigner and Frontiers Service) and the police. 'Successful inclusion' is conceived as a process of developing the 'right attitudes' in order to overcome community and individual 'vulnerabil-ities', to become, for example, an employable individual or an 'ideal pupil' in the education system. Within that framework, local communities, their ethno-racial heterogeneity and related 'vulnerabilities' are understood as objects for policy intervention. Accordingly, the external evaluation of the programme addressed the 'sensitivity' of project coordinators to the 'particularities' of the neighbourhoods where they intervene. Among the issues raised by those interviewed during the evaluation process, the report mentions what is described as 'the conflict inherent in the multicultural features of some locales', and highlights the following description given by a coordinator: '[The neighbourhood is characterized] by a strong multiculturality: Indians, Roma, Blacks. And where you could plainly perceive that the people did not mix.' This statement is followed by a diagram that highlights all the pro-blems identified by the projects funded in relation to the contexts in which they intervene, including deficits in 'parental competencies' or 'employability competencies', 'lack of life-projects', 'criminality' and 'difficulties in the inte-gration of immigrants and ethnic minorities'. 92

This report is the first of four that examined racism. ${ }^{93}$ Underlying the report is an understanding of racism as a question related to 'territorial identities' and how youths perceive their neighbourhoods. More specifically, it analyses the answers given by children and youths in a survey on the 'presence of racism in the neighbourhoods'. The report points out that 'interestingly, the group with the highest number of respondents reporting the existence of racism is "other Portuguese" [23.5 per cent]': ${ }^{94}$

\footnotetext{
... regarding the responses of the 'other Portuguese', the team's direct observation during the survey found that these young people placed themselves outside epi-sodes of racial conflict, stating that: 'There are problems between Blacks and Gypsies.' They adopted a position of mere spectators. Furthermore, it seems that racism can only materialize through physical violence and cannot take more or less subtle forms in various contexts of everyday interaction. Another likely expla-nation, which has not been tested, is the hypothesis that these young people live in ethnic neighbourhoods where the minority may be of Portuguese origin. ${ }^{95}$
}

92 Saint-Maurice (ed.), Avaliação Externa do Programa Escolhas 2010-2012, 69.

93 Racism was, for the first time, explicitly included as one of the programme's strategic areas ('Community Dynamization and Citizenship') in the last official directive for the 2013-15 period: 'Gabinete do Secretário de Estado Adjunto do Ministro Adjunto e dos Assuntos Parlamentares: Despacho normativo No. 17/2012', 29006.

94 Respondents had to answer yes or no to the following statement: 'My neighbourhood has racism problems'; 15 per cent of Roma respondents and 4.1 per cent of descen-dants of immigrants responded yes (Saint-Maurice (ed.), Avaliação Externa do Programa Escolhas 2010-2012, 93-7.

95 Ibid., 98. 
This explanation exposes a view that confines racism to social relations in contexts of ethnoracial diversity portrayed in a historical and political vacuum: power relations are neutralized in favour of interpretations of racism as associated with the presumed conflictive nature of ethnoracial diver-sity. Racism is displaced on to 'society', more precisely, on to the geographies of heterogeneity, that is, the ethnically marked Other. In fact, from the outset, aca-demic, political and policy discourses have presented the issue of 'cultural diversity' as a source of social problems - although often combined with ideas about its 'positive aspects' or the 'opportunities' it may bring-paving the way for the depoliticization of racism. 96 This was paramount, for instance, in the legal text that launched the Alto Comissariado para a Imigração e Mi-norias Étnicas (ACIME, High Commission for Immigration and Ethnic Mi-norities) in 2002: ' . . the problem of ethnic minorities, although distinct from that of immigration, has become more pronounced due to the cultural diversity characteristic of immigrant communities, with inevitable social con-flicts with the host society and mutual incomprehension. ${ }^{97}$ In this scenario, the 'host society' is portrayed as a community exposed to an unprecedented excess of cultural diversity.

With racism understood as a factor inherent to ethnoracial heterogeneity, antiracism becomes subsumed in the rhetoric of 'intercultural dialogue'. The idea of the 'encounter with difference' is linked to a strengthening of 'social cohesion', the combating of 'prejudice' and the 'sensitization' of majorities. It became evident over the course of our fieldwork that racism was usually avoided by policymakers, practitioners and local authorities. ${ }^{98}$ When, in our interviews, we posed questions about the relationship between integration, interculturality and anti-racism, responses revolved around descriptions of the cultural diversity of local communities or the pre-sumed characteristics of ethnically marked populations. Interviewees usually considered that referring to racism was 'not the best way to deal with ques-tions related to integration' because it stressed 'negative aspects'. 99 Accord-ingly, they assumed that racism was more positively addressed, albeit indirectly, via 'interculturality', which is seen as a process of fostering 'mutual understanding' between cultures within the heterogeneity of 'vulner-able environments'.

96 Araújo, 'Challenging narratives on diversity and immigration in Portugal'.

97 'Presidência do Conselho de Ministros. Decreto-Lei No. 251/2002', Diário da República, 1st Series-A, No. 270, 22 November 2002, 7328, available on the Diário da República Electrónica website at https://dre.pt/application/file/448804 (viewed 21 November 2016).

98 For further details, see Maeso and Araújo, 'The politics of (anti-)racism'; Araújo, 'A very "prudent integration"; and Silvia Rodríguez Maeso, "Civilising" the Roma?: the depoliticisation of (anti-)racism within the politics of integration', Identities: Global Studies in Culture and Power, vol. 22, no. 1, 2015, 53-70.

99 Representative of a public body responsible for intercultural dialogue interviewed by the authors, February 2010. 
It is undeniable that, in the contexts where we primarily work, because they are vulnerable environments where the most vulnerable communities live, these communities are often composed of immigrants and their descendants, right? Now, what we try to do within each project is to promote-as a message from the central coordination-an intercultural openness that has to be necessarily present in the different activities. Here in [a Lisbon neighbour-hood] we have the Lusos ${ }^{100}$ [laughter], who are Portuguese, just to simplify, right? Then there are descendants of immigrants, who may be descendants or the children may be immigrants themselves, that is, non-Portuguese. Then there are some Indians, and members of the Roma community. This is an example: four distinct groups . . . in the same context, targeted by the same project. This requires continuous work. ${ }^{101}$

Most consider that policies are needed to act on diversity, and racism is nar-rated as a universal social malaise that can be effectively overcome with better and greater knowledge of the Other. In the words of the former High Commis-sioner, in a text about racism entitled 'Prejudice Is in the Eye of the Beholder':

... no country can declare itself to be free from racism, and Portugal is no exception. The main source of discrimination is looking at others and not seeing people with inalienable human dignity, but seeing instead images and stereotypes imprinted in our minds, a result of prejudice accumulated through years of ignorance. The road of education for intercultural dialogue is a road leading to action against racial discrimination. Knowledge is therefore essential, because Portuguese social cohesion depends on the awareness of the value of interculturality as a factor of cultural and social enrichment. Con-sciousness-raising campaigns carried out by the ACIDI's Training Programme on Citizenship and Interculturality (Bolsa de Formadores) have played a vital role in that sense. ${ }^{102}$

Power relations in the production of knowledge are erased under this conventional formulation; 'intercultural training' is regarded as a solution to racism from the point of view of correcting erroneous knowledge about the Other, that is, reproducing assumptions in studies of prejudice and attitudes. Racism thus becomes a question of 'misunderstandings', overlooking debates on the histories of colonialism, power relations and structural discrimination. As we will demonstrate in our concluding remarks, any debate aimed at the systematic assessment of institutionalized racism is consistently disqualified.

100 This implicitly racial term is used as a synonym for 'white Portuguese', denoting a national ancestry that is ethnically homogeneous. The term was first popularized by Luís Vaz de Camões in his epic poem 'Os Lusíadas' (published 1572).

101 Regional coordinator of the Programa Escolhas, interviewed by the authors, Decem-ber 2010.

102 Rosário Farmhouse, 'O preconceito está no olhar', Revista ACIDI B-i, No. 79, 2010, 2. 


\section{The implausibility of racism in policy discourse and knowledge production}

Our analysis of the policy discourse on and approach to the monitoring of ethnoracial discrimination by European agencies-with a specific focus on school segregation of Roma students in Portugal-shows how contemporary politi-cal understandings of racism are designed to fail, in the sense that they preclude any discussion of its institutionalization in European liberal democracies. A critique of their political ineffectiveness in enforcing change is not new. In the last few years, the FRA has acknowledged that there is little commitment to tackling racism across the member states, including in education, noting: (a) the monitoring of inequalities has remained at a low level in most European member states, including Portugal; ${ }^{103}$ (b) the impact of political intervention has been very limited, and not 'accompanied by broader improvements of the education system as a whole. . . . many programmes suffer from a lack

of adequate funding and in many cases there is no evaluation of effectiveness and impact of measures'; ${ }^{104}$ and (c) while there was an increase in 'the number of strategies for the education of the Roma . . . discriminatory policies and practices against the Roma remained at a very high level in the EU'. ${ }^{105}$ Despite this acknowledgment, there should be a call for a change of approach, from one based on denunciation and awareness to one that systematically explores the relationship between public policies and ethnoracial inequalities across time and that provides reliable data about it. ${ }^{106}$ For instance, in the Por-tuguese context, what is the proportion of Roma and black youths enrolled in high status academic programmes compared to ethnically unmarked popu-lations? Or in professional training programmes? What is the rate of unem-ployment among Roma and black youths? How many Roma and black youths have found employment after temporary 'employability' internships during their participation in the Programa Escolhas?

Rather than data on discrimination, the policy framework for integration in the Portuguese context has focused on vulnerability. This is understood as a 'characteristic' of immigrants and minorities, thus informing the production of knowledge about the problems (that is, deficiencies) associated with certain communities and situations of ethnoracial heterogeneity. It is within this framework that we can make sense of the implausibility of racism as a

103 FRA, Annual Report 2008, 72-4; FRA, Annual Report 2009 (Vienna: FRA 2009), 12; FRA, Annual Report 2010 (Vienna: FRA), 67.

104 FRA, Annual Report 2009, 52.

105 FRA, 'Data collection and research activities on racism and xenophobia in the EUMC (1998-2006)', 101. Failure to bring about change was particularly visible in the case of D.H. and Others v. the Czech Republic, brought before the European Court of Human Rights (see FRA, Annual Report 2008, 16). A report published two years later noted the persistence of segregation in the Czech Republic (see FRA, Annual Report 2010, 66-7).

106 David Gillborn and Caroline Gipps, Recent Research on the Achievements of Ethnic Minority Pupils (London: HMSO 1996). 
political issue. Let us briefly examine a recent and widely reported case of segregation of Roma pupils in a state primary school in the municipality of Tomar. ${ }^{107}$ In September 2014, the school created a separate class with fourteen Roma pupils (aged 7 to 14), raising protests from the parents. The High Com-missioner for Migrations and also President of the CICDR, Pedro Calado, sent a letter to the school's principal asking for 'clarification' of the reasons for taking that decision. The High Commissioner stated to the press that, 'under the Portuguese Constitution', the case was 'frankly questionable' and, 'if one of the parties [in reference to the Roma families] is not satisfied, as in this case, we have to be even more critical'. However, he explicitly pointed out that 'discrimination complaints occur only rarely. We do not have a serious discrimination problem. ${ }^{108}$ In October, the Roma families com-plained that no changes had been made and the class remained segregated. ${ }^{109}$ At the time of writing, the High Commissioner has stated in a national news-paper that, although the situation was not 'good practice', the pupils in the class 'have performed well and have improved their behaviour in the class-room' 110 The headteacher of the school, Carlos Ribeiro, pointed out that there was no intention to segregate the students and that the criteria for the setting up of a separate form was the pupils' learning level. Ribeiro said that there was no plan to desegregate the class: 'We work on the basis of an inclusive policy and we did not receive any instructions from the Direcção Regional da Educação [Regional Director of Education] to close down the class.'11 ${ }^{11}$ These statements are paradigmatic of the politics of denial and evasion: whereas problems of 'early dropout', 'unsuccessful schooling' or 'discipline' are deemed to be 'characteristic' of the cultures of minorities - in this case, the Roma-and legitimate reasons for the creation of segregated classes, ${ }^{112}$ the acknowledgment of institutional responsibility in the reproduc-tion of discrimination and its embeddedness in the everyday operation of public bodies is out of the question. More importantly, despite the systematic critique by European agencies of the CICDR's lack of effectiveness in the

107 Central region of Portugal, with a population of 40,477 according to the latest census (2011).

108 Calado, quoted in Andreia Sanches, 'Pode o combate ao insucesso escolar justificar a separação de alunos por etnia?', Público (online), 25 September 2014, available on the Público website at www.publico.pt/n1670785 (viewed 23 November 2016).

109 News TSF, 'Tomar: Turma constituída apenas por ciganos mantém-se', 23 October 2014, available on the TSF website at www.tsf.pt/PaginaInicial/Interior.aspx? content_id=4196772 (viewed 23 November 2016).

110 Calado, quoted in Andreia Sanches, 'Turma de ciganos continua a dividir opiniões: Mas projecto é para acabar', Público (online), 2 February 2015, available on the Público website at www.publico.pt/n1684693 (viewed 23 November 2016).

111 Ribeiro, quoted in 'É prematuro anunciar extinção de turma de crianças ciganas em escola de Tomar', O Mirante, 4 February 2015, available on the O Mirante website at http://semanal.omirante.pt/index.asp?idEdicao $=690 \& \mathrm{id}=106772 \&$ idSeccao $=12319 \&$ Action=noticia\#.VOxmLCy3ER8 (viewed 6 December 2016).

112 Araújo, 'A very "prudent integration"'. 
collection and examination of discrimination complaints-and the public acknowledgment by decision-makers of the need for improvement in this area-it is the lack of complaints that is considered reliable evidence of the absence of a structural problem.

In sum, this article has shown the double operation taking place within the discourse of integration and diversity and its denial of racism: first, 'immigra-tion' and 'minority' issues seem to have brought the conversation about racism back to Europe; and, second, the need for public and private institutions to react and regulate the 'presence' of ethnically marked populations that 'inevi-tably' generate problems of 'integration'. Racism is understood as if it were external politics and thus pertaining to a universal problematics of cultural interactions/alterity.

Silvia Rodríguez Maeso is Principal Researcher at the Centre for Social Studies at the University of Coimbra. Her recent publications include The Con-tours of Eurocentrism: Race, History, and Political Texts (Lexington Books 2015), coauthored with Marta Araújo. Her research and teaching interests are focused on critical race theories, the politics of anti-racism and the critique of Eurocentrism. Email: srodrig@ces.uc.pt

Marta Araújo is Principal Researcher at the Centre for Social Studies at the University of Coimbra, where she also lectures at doctoral level. Her research interests centre on the (re)production and challenging of racism and Euro-centrism, with particular interest in education. Her recent publications include 'A very "prudent integration": white flight, school segregation and the depoliticization of (anti-)racism' (Race, Ethnicity and Education, 2016) and (with Silvia Rodríguez Maeso) The Contours of Eurocentrism: Race, History, and Political Texts (Lexington Books 2015). Email: marta@ ces.uc.pt 